
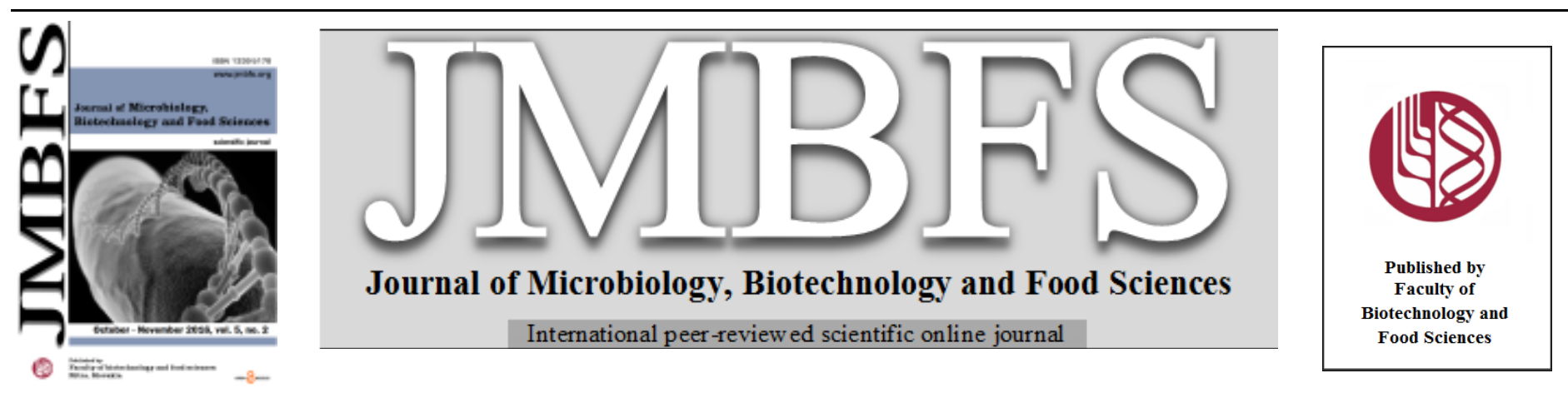

\title{
GROWTH AND BIOGENIC AMINE POTENTIAL OF Lactococcus lactis subsp. lactis, isolated FROM TURMERIC (Curcuma longa Linn.), WITH PROBIOTIC CHARACTERISTICS IN SKIM MILK
}

\section{Deepika Priyadarshani Wadumesthri, ${ }^{1, *}$, Plengpin Pianpumepong ${ }^{2}$}

Address(es): Dr. Deepika Priyadarshani Wadumesthri,

${ }^{1}$ Department of Biosystems Engineering, Faculty of Engineering, South Asian Institute of Technology and Medicine, Millennium Drive, Malabe, Sri Lanka. +94772357494:

${ }^{2}$ Department of Postharvest and Processing Engineering, Faculty of Engineering and Architecture, Rajamangala University of Technology Isan, 744 Suranari Road, Muang District, Nakhon Ratchasima 30000, Thailand.

*Corresponding author: deepika@saitm.edu.lk, dissanayake.deepika@ gmail.com

doi: 10.15414/jmbfs.2016.6.2.839-843

\section{ARTICLE INFO}

Received 1. 6. 2016

Revised 28. 6. 2016

Accepted 30. 7. 2016

Published 3. 10. 2016

Regular article open $\bigodot_{\text {access }}$

\begin{abstract}
The growth and biogenic amines, (BA), (histamine and tyramine) potential of Lactococcus lactis subsp. lactis with potential probiotic characteristics isolated from turmeric (Curcuma longa Linn.) was studied in skim milk. Probiotic characteristics were determined in terms of acid and bile tolerance, hydrophobicity and antimicrobial activity. Fermentation of skim milk was followed for 48 hrs at $37^{\circ} \mathrm{C}$ determining $\mathrm{pH}$, cell counts and histamine and tyramine with qualitative screening for proteolytic activity. Isolate showed good acid and bile salt tolerance (>90\%) with acceptable adhesion and antimicrobial activity. The maximum viable cell count $\left(8.35 \log \mathrm{cfu} \mathrm{mL}^{-1}\right)$ was observed after $48 \mathrm{hrs}$ of incubation in skim milk with corresponding low $\mathrm{pH}$ of 4.06 . Histamine or tyramine was not detected throughout $48 \mathrm{~h}$ of incubation as determined by HPLC. These properties suggest Lactococcus lactis subsp. lactis isolated from fresh turmeric is a safe potential probiotic in terms of BA production in milk.
\end{abstract}

Keywords: Biogenic amines, Histamine, Tyramine, Probiotic, Lactococcus lactis

\section{INTRODUCTION}

There is an increasing trend today in food industry to use probiotic starter cultures to promote the health and well being of the consumers. Probiotics are live microbial feed supplements which beneficially affects the host by improving the indigenous micro flora (Fuller, 1989). Lactic acid bacteria (LAB) play a major role as probiotic or functional starter organisms in food and beverage industry and are considered to have a safe history of application and consumption in fermented products (Wood et al., 1995; Caplice et al., 1999; Leroy et al., 2004). Lactobacillus and Lactococcus species are mainly used as probiotics in fermented milk products. Since Lactococcus strains are widely used as starter cultures, several works showed their application as probiotics in fermented dairy products (Grahn et al., 1994; Kimoto et al., 1999; Pianpumepong et al., 2012; Enan et al., 2013).

Strains with probiotic features were isolated from natural habitats or from fermented products (Oberman et al., 1998). The recent trend shows the isolation of wild-type of strains from traditional products to be used as starter or probiotic cultures in food fermentation (Beukes et al., 2001). LAB isolated from various kinds of fermented plant products show potential use as starter cultures with improved quality of the end products (Mourad et al., 2004; Prachyakij et al., 2008). However there is no reported evidence of potential probiotic bacteria isolated from turmeric rhizomes and use in milk fermentation. New or potential probiotic strains should be evaluated not only for their beneficial health effects, but also for their harmful metabolites. Biogenic amines (BA) are considered as undesirable metabolic product of probiotic or functional starter organisms with potential heath risk to consumers (Holzapfel et al., 1995; Leroy et al., 2004; Ammor et al., 2007).

Biogenic amines, histamine and tyramine are the most extensively studied amines in milk and milk products due to their toxicological effects. Histamine has been reported as the causative agent of histamine intoxication, while tyramine has been reported to affect the hypertensive crisis in the individuals being administrated monoamine oxidase (MAO) inhibitor drugs (Anderson et al., 1993; Silla Santos 1996; Zaman et al., 2009). The high amount of histamine and tyramine can be formed during storage or processing of fermented foods by the activity of bacterial decarboxylase enzyme (Halász et al., 1994). Accumulation of biogenic amines in fermented milk or cheese can be affected by the availability of free amino acids and the presence of decarboxylase positive microorganisms (Fernández-Garcia et al., 2000). Microorganisms possessing decarboxylase activity can be non-starter lactic acid bacteria and other spontaneous microflora (Roig-Sagués et al., 2002) and starter microorganism (Fernández-Garcia et al., 2000).

Several species of lactic acid bacteria have been identified as biogenic amines formers in milk. Several species of Lactobacillus bulgaricus, L. casei and $L$ acidophilus are reported as histamine formers (Edwards et al., 1981; Stratton et al., 1991; Petridis et al., 1996). According to Chander et al., (1989) Lactococcus lactis was found to produce histamine, tyramine and tryptamine. As reported by González de Llano et al., (1998); Halász et al., (1994); and Straub et al., (1995) amine forming ability should be one of the concerns in selecting starter cultures. Thus testing for BA formation by commonly used or intended to use starter or probiotic LAB strains is essential. However sufficient progress has not yet been made in the optimal strains selection in terms of BA formation and information relevant to the BA formation by probiotic Lactococcus lactis subsp lactis in milk system is still scarce.

Therefore, the aim of this study was to study the growth characteristics and biogenic amine potential of non dairy based Lactococcus lactis subsp lactis isolated from fresh turmeric rhizomes during the fermentation of skim milk.

\section{MATERIAL AND METHODS}

Isolation and Identification of Lactic Acid Bacteria (LAB)

Fresh turmeric rhizomes were purchased from Thakun, Suraththani Province, Thailand. Lactic acid bacteria were isolated and identified and characterized as previously reported (Adnan et al., 2007; Pianpumepong et al., 2010). In brief, $10 \mathrm{~g}$ of chopped turmeric rhizomes was mixed with $90 \mathrm{~mL}$ of sterile distilled water and extracted for 2 min using stomacher. Serial dilutions in sterile $\mathrm{NaCl}$ $(0.85 \%)$ were prepared with the $1 \mathrm{~mL}$ of extracted suspension. Diluted suspension $(0.1 \mathrm{~mL}$ ) was spread on MRS agar (Himedia, Mumbai, India) plates containing $0.5 \%(\mathrm{w} / \mathrm{v})$ calcium carbonate solution and incubated anaerobically at $37{ }^{\circ} \mathrm{C}$ for $24-48 \mathrm{hrs}$. Acid producing bacteria were recognized by the appearance of clear zone around the colonies. The purity of the colonies was examined on MRS agar plates containing $0.06 \mathrm{~g} \mathrm{~L}^{-1}$ bromocresol purple as an indicator. The 
medium colour changed from purple to yellow as a result of $\mathrm{pH}$ reduction indicating the production of a lot of lactic acid during the log phase of bacterial growth. Isolates were tested for catalase production by placing a drop of hydrogen peroxide solution $(3 \%(\mathrm{v} / \mathrm{v})$ in sterile distilled water) on bacterial cells. Immediate formation of bubbles indicated the presence of catalase in the cells. Following the catalase test isolates were further analyzed and identified by using API kits (bioMérieux, Inc., Durham, NC, USA).

\section{Probiotic Characterization}

Probiotic characteristics of the strain Lactococcus lactis subsp. lactis were investigated as acid and bile salt tolerance, hydrophobicity, and antimicrobial activity. Acid tolerance was tested as reported by Pianpumepong $\boldsymbol{e t}$ al., (2010). Cell suspension was added to MRS broth maintained at $\mathrm{pH} 3.0$ and a control at $\mathrm{pH} 6.4$ and incubated for $2 \mathrm{~h}$ at $37^{\circ} \mathrm{C}$. At the end of $2 \mathrm{~h}$ incubation viable cel count was determined by growing them in MRS agar for $48 \mathrm{hrs}$ at $37{ }^{\circ} \mathrm{C}$. Acid tolerance was measured as percentage of cell survival calculated by comparing the initial bacterial cell count to the count after $2 \mathrm{~h}$ incubation at $\mathrm{pH}$ 3.0. Bile salt tolerance was observed as reported by Pianpumepong $\boldsymbol{e t}$ al., (2010). Bacteria cell count was compared to the cell count in MRS broth with added bile salt and without bile salt after $24 \mathrm{~h}$ of incubation. Antibacterial activity was tested against Escherichia coli, Staphylococcus aureus, and Salmonella spp. and hydrophobicity and antimicrobial activity were calculated as reported by Pianpumepong et al., (2010).

Lactococcus lactis subsp. lactis with potential probiotic characteristics was further studied for their growth characteristics and biogenic amine potential in skim milk.

\section{Preparation of Inocula}

The strain Lactococcus. lactis subsp. lactis was maintained along with other isolated bacterial strains at the culture stocks of Biotechnology Laboratory of the Asian Institute of Technology, Pathumthani, Thailand. Prior to the inoculation the strain was subcultured ten times in MRS broth containing $0.1 \%$ histidine (Serva, Heidelberg, Germany), $0.1 \%$ tyrosine di-sodium salt (Biochemica, Hessen, Germany) and $0.005 \%$ pyridoxal-5-phosphate (Sigma Aldrich, Buchs, Switzerland) according to the previously described method (Bover-Cid et al., 1999) in order to enhance amino acid decarboxylase activity.

\section{Preparation of Milk Samples}

Powdered skim milk (Himedia, Mumbai, India) was reconstituted with distilled water $(10 \%)$, sterilized at $121{ }^{\circ} \mathrm{C}$ for $5 \mathrm{~min}$ according to the manufacturer's specification and analyzed for microorganisms, $\mathrm{pH}$ and biogenic amines histamine and tyramine prior to the inoculation. The sub cultured strain was aseptically added to the milk at the rate of $1 \%$ (v:v) and incubated at $37{ }^{\circ} \mathrm{C}$ for 48 hrs. Samples were taken at $6 \mathrm{hrs}$ interval within first $24 \mathrm{hrs}$ and then after $24 \mathrm{hrs}$ interval and analyzed for $\mathrm{pH}$, titratable acidity, colony forming units and biogenic amines, histamine and tyramine. Two replicates were done for the analysis.

\section{Determination of Viable Cell Count}

Samples of the sterilized reconstituted skim milk were analyzed for mesophilic bacteria (APHA, 1992). Mesophilic counts were obtained for $10^{\circ}$ and $10^{-1}$ dilutions on plate count and MRS agar after $48 \mathrm{hrs}$ of incubation at $37{ }^{\circ} \mathrm{C}$. Milk samples were serially diluted by 10 fold in $0.5 \%$ sterile peptone water. Serial dilutions (sample volume of $0.1 \mathrm{~mL}$ ) were plated on MRS agar (Himedia, Mumbai, India) and inverted plates were incubated at $37{ }^{\circ} \mathrm{C}$ for $48 \mathrm{hrs}$ Petridishes with 30- 300 separate colonies with white, smooth appearance were selected for the enumeration and number of colony forming units was recorded per $\mathrm{mL}$ of sample.

\section{Determination of $\mathbf{p H}$}

The fermented milk samples with L. lactic subsp. lactis were tested for $\mathrm{pH}$. The $\mathrm{pH}$ was measured using an electronic $\mathrm{pH}$ meter (Model Jenway 3310, Stone, Staffordshire ST15, OSA, UK). The $\mathrm{pH}$ meter was calibrated using standard buffer solutions (Merck, Darmstadt, Germany) of $\mathrm{pH} 4.0$ and 7.0 prior to the analysis.

\section{Screening for Proteolytic Activity}

Proteolytic activity of the selected strain was qualitatively screened in MRS agar plates supplemented with $10 \%$ skim milk. Medium plates were bored with sterile cork borer. Strains $(500 \mu \mathrm{l})$ were inoculated into the holes and incubated at $37{ }^{\circ} \mathrm{C}$ for 4 days. Proteolytic activity was recognized by the clear halo around the colonies.

\section{Determination of Biogenic Amines, Histamine and Tyramine}

Biogenic amines in milk samples were extracted according to the previously described method of Santos et al., (2003). The filtered supernatants were stored at $-20{ }^{\circ} \mathrm{C}$ until BA analysis. The amines were separated and quantified by HPLC, following the procedure optimized in this laboratory (Priyadarshani et al., 2011) with a little modification, using similar equipment and chromatographic conditions. The pre-column derivatization of acid extract was done similarly to the conditions described by Priyadarshani et al., (2011), but with addition of $200 \mu \mathrm{l}$ of $\mathrm{NaOH}$ instead of $20 \mu \mathrm{l}$. The identification of amines was performed by comparison of retention times of amines in samples to standard solutions spiked to milk. Quantification of histamine and tyramine was done by using externa calibration lines prepared with recovery data obtained by spiking known amounts $\left(0.5-200 \mathrm{mgL}^{-1}\right)$ of standard histamine and tyramine to the milk samples followed by extraction and HPLC analysis. The linear regression equations between recovered $\mathrm{BA}$ and peak areas are $\mathrm{y}=460333+69183 \mathrm{x}$ and $\mathrm{y}=303311+46289 \mathrm{x}$ for histamine and tyramine respectively with correspending correlation coefficient of 0.9929 and 9948. All the samples and replicates were injected at least in duplicate to the HPLC column. The quantity of each amine was expressed in $\mathrm{mgL}^{-1}$ milk.

\section{Statistical Analysis}

Statistically significant differences were evaluated by one-way analysis of variance with Fisher's LSD test at a $95 \%$ significance level using Minitab (version 14) statistical software.

\section{RESULTS}

\section{Screening for Lactic Acid Bacteria (LAB)}

The MRS medium was used to isolate the lactic acid bacteria from fresh turmeric rhizome. The LAB was selected from the colonies on MRS plus bromocresol purple agar. The colour of the media changed to yellow indicating the acid production. The isolates were found Gram positive and catalase negative (data not shown). The isolates were further specifically identified at species level by API 50 CHL media. A strain of Lactococcus lactis subsp. lactis was used for further tests.

\section{Probiotic Characterization}

Probiotic characterization was determined by acid and bile salt tolerance hydrophobicity, and antimicrobial activity. The LAB strain, Lactococcus lactis subsp. lactis isolated from fresh turmeric rhizomes showed important probiotic characteristics as shown in the Table 1.

Table 1 Probiotic characteristics of L. lactis subsp. lactis isolated from fresh turmeric rhizomes

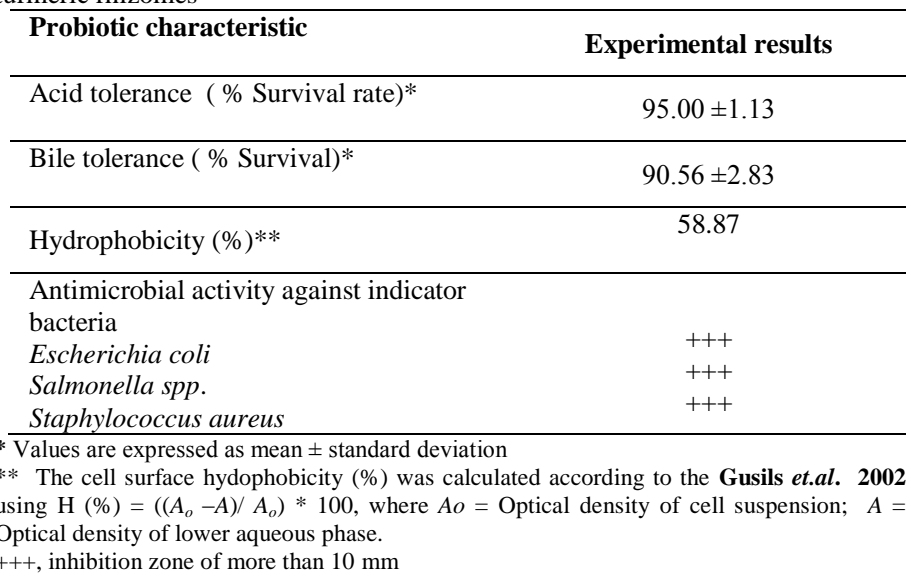

+++ , inhibition zone of more than $10 \mathrm{~mm}$

\section{Characteristics of Sterilized Reconstituted Skim Milk}

Microbial counts on sterile skim milk are shown in Table 2. The initial $\mathrm{pH}$ of the milk samples were varied in between 6.6 to 6.8. The variation could be expected due to the variation of $\mathrm{pH}$ in the distilled water used to prepare milk samples and different lots of powdered milk used in the same brand. No histamine or tyramine was detected in the sterilized reconstituted skim milk samples. 
Table 2 Colony forming units of mesophilic bacteria in sterilized skim milk samples

\begin{tabular}{lcccc}
\hline \multirow{3}{*}{ Milk Sample } & \multicolumn{3}{c}{ Colony forming Units per $\mathbf{~ L L}$} \\
\cline { 2 - 5 } & \multicolumn{2}{c}{ Total Plate Count Agar } & \multicolumn{2}{c}{ MRS agar } \\
\cline { 2 - 5 } & $\mathbf{1 0}^{\mathbf{0}}$ & $\mathbf{1 0}^{-1}$ & $\mathbf{1 0}^{\mathbf{0}}$ & $\mathbf{1 0}^{-\mathbf{1}}$ \\
\hline 1 & 0.5 & 0 & 0 & 0 \\
2 & 0 & 0 & 0 & 0 \\
3 & 0 & 0 & 0 & 0 \\
\hline Values are mean value for duplicate analysis &
\end{tabular}

\section{Growth Characteristics of Lactococcus lactis subsp. lactis in Skim Milk}

The growth study showed that the probiotic Lactococcus lactis subsp. lactis grow well in skim milk. Growth of the strain is shown in Figure 1A. The initial viable cell count was $7.15 \log \mathrm{cfu} \mathrm{mL}^{-1}$. The strain attained maximum viable cell number of $8.35 \mathrm{log}$ cfu $\mathrm{mL}^{-1}$ after $48 \mathrm{hrs}$ of incubation. The $\mathrm{pH}$ of the skim milk inoculated with $L$. lactis subsp. lactis decreased from 6.8 initially to 4.06 after 48 hrs of incubation (Figure 1B).

The analysis of proteolytic activity on skim milk agar plates revealed that tested strain of L. lactis subsp. lactis did not show clear proteinase activity as clear hallo around the colonies after 4 days of incubation was not observed (Figure 2).

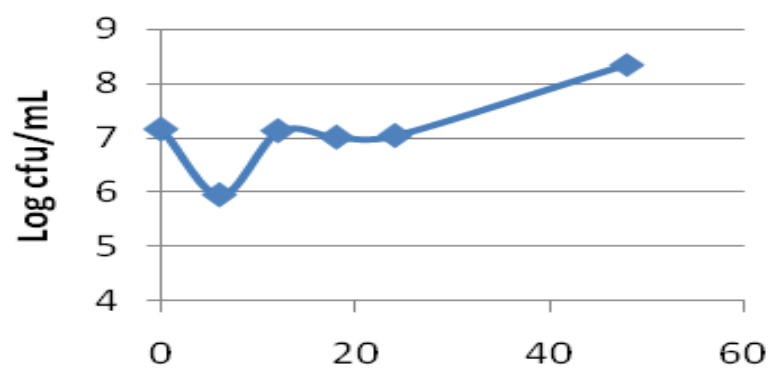

Fermentation time (hrs)

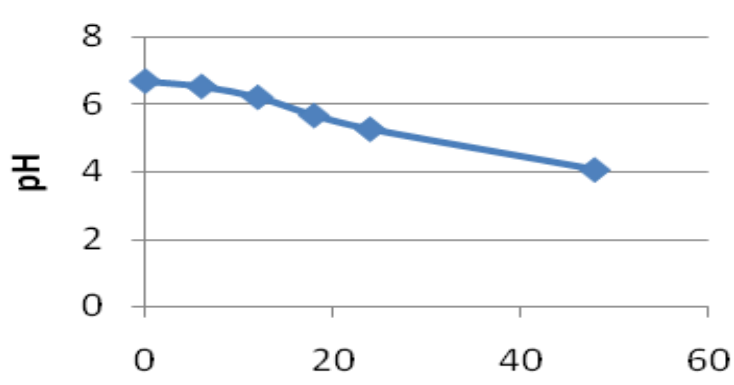

Fermentation time (hrs)

Figure 1 (A-B): A: Total colony forming units $\log \mathrm{CFU} \mathrm{mL}{ }^{-1} ; \quad \mathrm{B}: \mathrm{pH}$ of reconstituted and sterilized skim milk fermented with Lactococcus lactis subsp. Lactis, isolated from turmeric rhizomes. Results are the average of the duplicate treatments

Biogenic Amine (Histamine and Tyramine) Formation by L. lactis subsp. lactis in Skim Milk

Quantification was done by exploration of the standard calibration curves prepared from peak areas obtained by recovered amines spiked to skim milk. Calibration lines for both histamine and tyramine were constructed separately by plotting peak height vs. amount of amine. Linear regression analysis was performed for obtained data. The results of regression analysis were shown in the Table 3. The correlation coefficient for both histamine and tyramine were found to be 0.99 . Therefore it is revealed that there is a linear relationship between amount of amine and detector response. This further indicated that the method applied for derivatization and HPLC analysis in this study was satisfactory. Potential to produce histamine and tyramine in milk during fermentation was not observed for the probiotic Lactococcus lactis subsp. lactis (Figure 3) as none of the amines were detected.

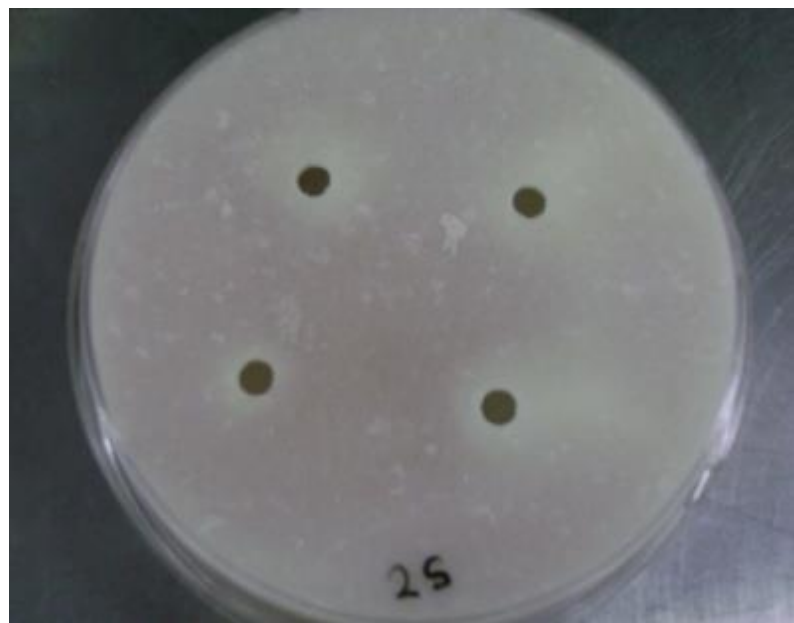

Figure 2 Proteolytic activity of strain Lactococcus lactis subsp. Lactis isolated from fresh turmeric rhizomes after 4 days incubation at $37^{\circ} \mathrm{C}$ on skim milk

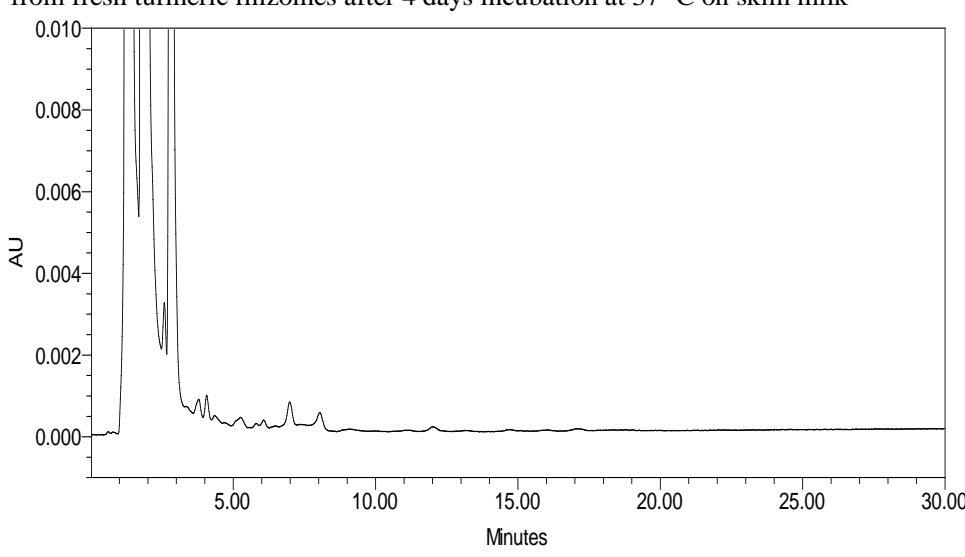

A

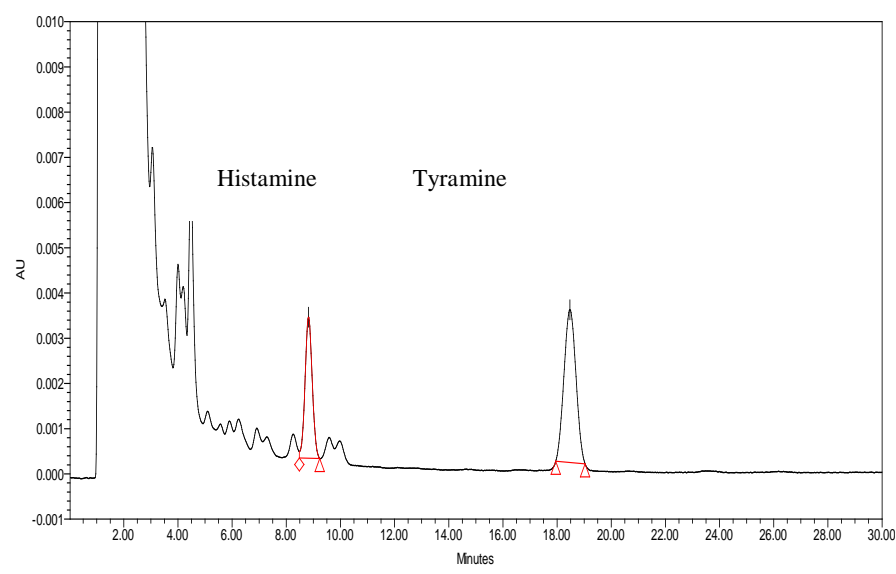

Figure 3 Representative HPLC chromatograms of skim milk A: inoculated with Lactococcus lactis subsp. lactis isolated from fresh turmeric rhizomes after $48 \mathrm{hrs}$ of incubation at $37^{\circ} \mathrm{C}$. B: spiked with authentic biogenic amines, histamine and tyramine $5 \mathrm{mgL}^{-1}$

\section{DISCUSSION}

A non-dairy based Lactococcus lactis subsp. lactis was isolated from fresh turmeric rhizomes using MRS medium. Isolate was found Gram-positive and catalase negative. The strain was specifically identified by API 50 CHL media at species level. The probiotic isolate was selected based on acid tolerance, bile salt tolerance, hydrophobicity and antimicrobial activity. The ability to resist low $\mathrm{pH}$ is an important selection criterion for probiotic microorganisms as acidic gastric juice in stomach destroys most of the ingested microorganisms. As reported by Pianpumepong et al., (2010), L. lactis subsp. lactis was able to tolerate $2 \mathrm{~h}$ of acid exposure at $\mathrm{pH} 3$ and with good survival rate at $0.3 \%$ bile salt. The ability of LAB to survive the passage through acidic media is variable and strain dependant. The survival rate of approximately $85 \%$ is considered to be very 
significant for the probiotic field (Fernádez et al., 2003; Pennacchia et al., 2004). The isolated strain showed $>90 \%$ of survival rate at both low $\mathrm{pH}$ and bile salt.

Adhesion to intestinal surfaces is an important property of probiotic bacteria. The hydrophobicity test was used to demonstrate adhesion capacity of the culture to the intestinal epithelium of the host. Several studies revealed the possibility of Lactococcus strains to be present in the human or animal gastrointestinal tract (Gruzza et al., 1992; Klijn et al., 1995). According to Kimoto et al., (1999) highest adhesion rate is observed with Lactococcus lactis subsp. lactis NIAI527. The turmeric derived L. lactis subsp. lactis studied in present study showed $>50$ $\%$ adhesive capacity.

The isolate was found to produce strong inhibition zones (zone of inhibition of more than $10 \mathrm{~mm}$ ) against three indicator organisms. The high antagonistic activity was demonstrated against Escherichia coli, Staphylococcus aureus, and Salmonella spp. which are considered to be disease causing agents in the lower digestive tract in human. Similar to this study Enan et al., (2013) shows the antibacterial activity of Lactococcus lactis subsp. lactis $\mathrm{Z}_{11}$ isolated from Zabady (Arabian yoghurt) against Listeria monocytogenes, Bacillus cereus and Staphylococcus aureus.

The growth and survival of probiotic bacteria in milk and milk products are affected by various factors. Some of these are: acid and hydrogen peroxide formation by yoghurt starter; availability and content of oxygen in milk, package, and temperature. (Bolduca et al., 2006; Shah, 2000a). Moreover their growth and survival was found to be affected by milk composition (chemical and microbiological), amount of milk solids and nutrient availability (Shah, 2000b). Among probiotics Lactococci have numerous nutritional requirements for growth, especially nitrogen sources (Law et al., 1976) and amino acid requirement reported to be strain dependent (Chopin, 1993). They utilize peptides or proteins as nitrogen sources through proteolytic enzyme activity (Leitão et al., 2000). The content of these compounds are low in raw milk. Hence presence of proteolytic system is an important aspect for probiotic lactic acid bacteria which are used in food fermentation (Kojic et al. 1991). The $\mathrm{pH}$ reduction during incubation enhances the proteolysis to liberate short peptides and free amino acids. Presence of proteinase enzymes then enhances the growth in milk. The present study revealed the proteinase negative (Prt') characteristics as milk protein degradation was not observed on the skim milk agar plates. Sharp reduction in $\mathrm{pH}$ during first $24 \mathrm{~h}$ of incubation was not observed in L. lactis subsp. lactis in milk when compared to other strains studied (data not shown) Similarly to this study Durlu-Ozkaya, (2001) reports slow acidifying activity of L. lactis subsp. lactis strains in milk at $30{ }^{\circ} \mathrm{C}$. In this study, highest viable coun of $8.35 \log$ cfu mL- with concomitant low $\mathrm{pH}$ of the medium was observed at the $48 \mathrm{~h}$ of incubation.

Many factors are needed to be fulfilled in order to accumulate BA in milk. The factors of concern are: availability of precursor amino acids; presence of decarboxylase positive microorganisms and availability of proper conditions for growth and decarboxylation (ten Brink et al., 1990; Russo et al., 2010). Various factors are related to such conditions in milk such as milk treatments, use of starter cultures and enzymes, the duration and the temperature of fermentation, the level of proteolysis, the $\mathrm{pH}$, the $\mathrm{NaCl}$ concentration, the presence of oxygen, the activity of water and relative humidity, the bacterial density and water activity and synergetic effects (Gardini $\boldsymbol{e t}$ al., 2001). The main producers of BA in milk and milk products are LAB including Enterococcus, Lactobacillus, Leuconostoc, Lactococcus and Streptococcus (Bonetta et al., 2008; CallesEnríquez et al., 2010; Linares et.al., 2012). However, biogenic amine production by the Lactococcus strains has not been much documented.

de Llano et al., (1998) has reported high level of tyramine production by wild dairy L. lactis subsp. lactis in decarboxylase broth supplemented with amino acid precursors. But no tyramine production was detected in cultures of these strains grown in milk. However, evolution of tyramine production is observed in skim milk supplemented with tyrosine after $18 \mathrm{~h}$ of incubation. In contrast, DurluOzkaya et al., (2001) report decarboxylase negative strains of L. lactis subsp. lactis isolated from Beyaz cheese made from raw ewes' milk. In the present study no histamine or tyramine production was detected in milk cultured with L. lactis subsp. lactis strain isolated from turmeric throughout the $48 \mathrm{~h}$ of incubation time.

\section{CONCLUSION}

This study showed that Lactococcus lactis subsp. lactis isolated from fresh turmeric rhizomes carries potential probiotic characteristics and does not produce histamine and tyramine in fermented milk. This suggests Lactococcus lactis subsp. lactis isolated from turmeric as a potential non dairy based functional starter. However results of BA formation by the same strain in laboratory media will not imply the similar behavior in complex food matrixes. This makes the situation more complex and implies that tests on the probiotics for amine production in the food matrix into which it is planned to be applied should be done for positive BA producers. BA production capability should be an important criterion for choice of probiotic and starter cultures and only those strains not producing BA should be used as probiotics or functional starter cultures.

\section{REFERENCES}

Adnan, A.F.M., \& Tan, I.K.P. (2007). Isolation of lactic acid bacteria from Malaysian foods and assessment of the isolates for industrial potential $\begin{array}{lll}\text { Bioresource Tech., } & \text { 98, 1380-1385 }\end{array}$ http://dx.doi.org/10.1016/j.biortech.2006.05.034

Ammor, M.S., \& Mayo, B. (2007). Selection criteria for lactic acid bacteria to be used as functional starter cultures in dry sausage production: An update. Meat Sci., 76, 138-146. http://dx.doi.org/10.1016/j.meatsci.2006.10.022

Anderson, M.C., Hasan, F., McCrodden, J.M., \& Tipton, K.F. (1993) Monoamine oxidase inhibitors and the cheese effect. Neurochem. Res., 18, 1145 1149. http://dx.doi.org/10.1007/bf00978365

Beukes, E.M., Bester, B.H., \& Mostert, J.F. (2001). The microbiology of South African traditional fermented milk. Int. J. Food Microbiol., 63, 189-197. http://dx.doi.org/10.1016/s0168-1605(00)00417-7

Bonetta, S., Bonetta, S., Carraro, E., Coisson, J.D., Travaglia, F., \& Arlorio, M. (2008). Detection of biogenic amine producer bacteria in a typical Italian goat cheese. J. Food Prot., 71, 205-209.

Bolduca, M.P., Raymond, Y., Fustier, P., Champagne, C.P., \& Vuillemard, J.C (2006). Sensitivity of bifidobacteria to oxygen and redox potential in nonfermented pasteurized milk. Int. Dairy., 16, 1038-1048. http://dx.doi.org/10.1016/j.idairyj.2005.10.030

Bover-Cid, S., \& Holzapfel, W.H. (1999). Improved screening procedure for biogenic amine production by lactic acid bacteria. Int. J. Food Microbiol., 59, 391-396. http://dx.doi.org/10.1016/s0168-1605(99)00152-x

Calles-Enriques, M., Eriksen, B.H., Andersen, P.S., Rattray, F.P., Johansen, A.H., Fernandez, M., Ladero, V., \& Álvarez, M.A. (2010). Sequencing and Transcriptional analysis of the Streptococcus thermophilus histamine biosynthesis gene cluster: factors that affect differential hdcA expression. Appl. Environ. Microbiol., 76, 6231-6238. http://dx.doi.org/10.1128/aem.00827-10

Caplice, E., \& Fitzgerald, G.F. (1999). Food fermentations: role of microorganisms in food production and preservation. Int. J. Food Microbiol., 50, 131-149.

Chander, H., Batish, V.H., Babu, S., \& Singh, R.S. (1989). Factors affecting amine production by selected strain of Lactobacillus bulgaricus. J. Food Sci., 54, 940-942. http://dx.doi.org/10.1111/j.1365-2621.1989.tb07917.x

Chopin, A. (1993). Organization and regulation of genes for amino acid biosynthesis in lactic acid bacteria. FEMS Microbiol. Rev., 12, 21-38.

de Llano, D.G., Cuesta, P., \& Rodriguez, A. (1998). Biogenic amine production by wild lactococcal and leuconostoc strains. Lett. App. Microbiol., 26, 270-274. http://dx.doi.org/10.1046/j.1472-765x.1998.00320.x

Durlu-Ozkaya, F., Xanthopoulos, V., Tunail,. N., \& Litopoulou-Tzanetaki, E. (2001). Technologically important properties of lactic acid bacteria isolates from Beyaz cheese made from raw ewes' milk. J. Appl. Microbiol., 91, 861-870 http://dx.doi.org/10.1046/j.1365-2672.2001.01448.x

Edwards, S.T., \& Sandine, W.E. (1981). Public health significance of amines in cheese. J. Dairy Sci., 64, 2431-2438. http://dx.doi.org/10.3168/jds.s0022$\underline{0302(81) 82868-8}$

Enan, G., Abdel-Shafi, S., Ouda, S., \& Negm, S. (2013). Novel antibacterial activity of Lactococcus lactis subspecies lactis $\mathrm{Z}_{11}$ isolated from Zabady. Int. J. BioMed. Sci., 9(3), 174-180.

Fernández, M.F., Boris, S., \& Barbés, C. (2003). Probiotic properties of human Lactobacilli strains to be used in the gastrointestinal tract. J. App. Microbiol., 94(3), 449-455. http://dx.doi.org/10.1046/j.1365-2672.2003.01850.x

Fernández-García, E., Tomillo, J., \& Nunez, M. (2000). Formation of biogenic amines in raw milk Hispánico cheese manufactured with proteinases and different levels of starter culture. J. Food Prot., 63, 1551-1555.

Fuller, R. (1989). Probiotics in man and animals. J. Appl. Bacteriol., 66, 365-378 http://dx.doi.org/10.1111/j.1365-2672.1989.tb05105.x

Gardini, F., Martuscelli, M., Caruso, M.C., Galgano, F., Crudele, M.A., Favati, F., Guerzoni, M.E., \& Suzzi, G. (2001). Effect of pH, temperature and $\mathrm{NaCl}$ concentration on the growth kinetic, proteolytic activity and biogenic amines production of Enterococcus faecalis. Int. J. Food Microbiol., 64, 105-117. http://dx.doi.org/10.1016/s0168-1605(00)00445-1

González de Llano, G., Cuesta, P., \& Rodríguez, A. (1998). Biogenic amine production by wild lactococcal and leuconostoc strains. Lett. Applied Microbiol., 26(4), 270-274. http://dx.doi.org/10.1046/j.1472-765x.1998.00320.x

Grahn, E., Holm, S.E., Lilja, H., \& Sellgren, K. (1994). Interference of a Lactococcus lactis strain on the human gut flora and its capacity to pass the stomach and intestine. Scandin. J. Nutri., 38, 2-4.

Gruzza, M., Duval-Iflah, Y., \& Ducluzeau, R. (1992). Colonization of the digestive tract of germ-free mice by genetically engineered strains of Lactococcus lactis: study of recombinant DNA stability. Microbial. Rele., 1, 165171

Gusils, C., Bujazha, M., \& González, S. (2002). Preliminary studies to design a probiotic for use in swine feed. Interciencia, 27, 409-413.

Halász, A., Baráth, A., Simon-Sarkadi, L., \& Holzapfel, W. (1994). Biogenic amines and their production by microorganisms in food. Trends. Food Sci. Technol., 5, 42-49. http://dx.doi.org/10.1016/0924-2244(94)90070-1 
Holzapfel, W.H., Geisen, R., \& Schillinger, U. (1995). Biological preservation of foods with reference to protective cultures, bacteriocins and food-grade enzymes Int. J. Food Microbiol., 24(3), 343-362. http://dx.doi.org/10.1016/0168 1605(94)00036-6

Kimoto, H., Kurisaki, J., Tsuji, N.M., Ohmomo, S., \& Okamoto, T. (1999). Lactococci as probiotic strains: adhesion to human enterocyte-like Caco-2 cells and tolerance to low $\mathrm{pH}$ and bile. Lett. App. Microbiol., 29(5), 313-316. http://dx.doi.org/10.1046/j.1365-2672.1999.00627.x

Klijin, N., Weerkamp, A.H., \& De Vos, W.M. (1995). Genetic making of Lactococcus lactis shows its survival in the human gastrointestinal tract. Appl. Envi. Microbiol., 61, 2771-2774.

Kojic, M., Fira, D., Banina, A., \& Topisirovic, L. (1991). Characterization of the cell wall-bound proteinase of Lactobacillus casei HN14. Appl. Envi. Microbiol., 57, 1753-1757.

Law, B.A., Sezgin, E., \& Sharpe, M.E. (1976). Amino acid nutrition of some commercial cheese starters in relation to their growth in supplemented whey media. J. Dairy Res., 43, 291-300. http://dx.doi.org/10.1017/s0022029900015855 Leitão, M.C., Teixeira, H.C., Barreto Crespo, M.T., \& San Romão, M.V. (2000) Biogenic amines occurrence in wine: amino acid decarboxylase and proteolytic activities expression by Oenococcus oeni. J. Agric. Food Chem., 48(7), 27802784. http://dx.doi.org/10.1021/jf991135v

Leroy, F., \& De Vuyst, L. (2004). Lactic acid bacteria as functional starte cultures for the food fermentation industry. Trends Food Sci. Technol., 15(2), 67-7. http://dx.doi.org/10.1016/j.tifs.2003.09.004

Linares, D.M., Rio, B.D., Ladero, V., Martínez, N., Fernández, M., Martín, M.C., \& Álvarez, M.A. (2012). Factors influencing biogenic amines accumulation in $\begin{array}{llll}\text { dairy products. } & \text { Fron. } & \text { Microbiol., } & 3,10 .\end{array}$ http://dx.doi.org/10.3389/fmicb.2012.00180

Mourad, K., Halima, Z., \& Nour-Eddine, K. (2004). Isolation of lactic acid bacteria for its possible use in the fermentation of green Algerian olives. Grasas y Aceites., 55, 385-393. http://dx.doi.org/10.3989/gya.2004.v55.i4.205

Oberman, H., \& Libudzisz, Z. (1998). Fermented milks. In Microbiology of fermented foods, (Vol. 1), Wood, B.J.B. ed., London: Blackie Academic \& Professional. http://dx.doi.org/10.1007/978-1-4613-0309-1_11

Pennacchia, C., Ercolini, D., Blaiotta, G., Pepe, O., Mauriello, G., \& Villani, F. (2004). Selection of Lactobacillus strains from fermented sausages for their potential use as probiotics. Meat Sc. 67(2), 309-317. http://dx.doi.org/10.1016/j.meatsci.2003.11.003

Petridis, K.D., \& Steinhart, H. (1996). Biogenic amines in hard cheese production. I. Factors influencing the biogenic amine content in end-product by way of Swiss cheese. Deutsches Lebensmittel-Rund-schau., 92, 114-120.

Pianpumepong, P., \& Noomhorm, A. (2010). Isolation of probiotic bacteria from turmeric (Curcuma lona Linn.) and its application in enriched beverages. Int. J. Food Sc. Tech., 45, 2426-2462. $\quad$ http://dx.doi.org/10.1111/j.13652621.2010.02337.x

Pianpumepong, P., Anal, A.K., Doungchawee, G., \& Noomhorm, A. (2012) Study on enhanced absorption of phenolic compounds of Lactobacillus fermented turmeric (Curcuma longa Linn.) beverage in rats. Int. J. Food Sc. Tech., 47(11), 2380-2387. http://dx.doi.org/10.1111/j.1365-2621.2012.03113.x

Prachyakij, P., Chareenjiratrakul, W., \& Kantachote, D. (2008). Improvement in the quality of a fermented seaweed beverage using an antiyeast starter of Lactobacillus plantarum DW3 and partial sterilization. World J. Microbiol \& Biotech., 24(9), 1713-1720. http://dx.doi.org/10.1007/s11274-008-9662-1

Priyadarshani, W.M.D., \& Rakshit, S.K. (2011). Screening selected strains of probiotic lactic acid bacteria for their ability to produce biogenic amines (histamine and tyramine). Int. J. Food Sci. Technol., 46(10), 2062-2069. http://dx.doi.org/10.1111/j.1365-2621.2011.02717.x

Roig-Sagués, A.X., Molina, A.P., \& Hernándes-Herrero, M.M. (2002) Histamine and tyramine-forming microorganisms in Spanish traditional cheese Eur. Food Res. Tech., 215(2), 96-100. http://dx.doi.org/10.1007/s00217-002$\underline{0521-2}$

Russo, P., Spano, G., Arena, M.P., Capozzi, V., Grieco, F., \& Beneduece, L. (2010). Are consumers aware of the risks related to biogenic amines in food? Curr Res. Technol. Edu. Top. Appl. Microbiol. Microb. Biotechnol., 1087-1095.

Santos, W.C., Souza, M.R., Cerqueira, M.M.O.P., \& Glória, M.B.A. (2003). Bioactive amine formation in milk by Lactococcus in the presence or not of rennet and $\mathrm{NaCl}$ at 20 and $32{ }^{\circ} \mathrm{C}$. Food Chem., 81(4), 595-606 http://dx.doi.org/10.1016/s0308-8146(02)00502-2

Shah, N.P. (2000a). Probiotic bacteria: selective enumeration and survival in Dairy food. J. Dairy Sci., 83(4),894-907. http://dx.doi.org/10.3168/jds.s00220302(00)74953-8

Shah, N.P. (2000b). Effect of milk derived bioactive: an overview. Brit. J. Nutrit., 84, S3-S10. http://dx.doi.org/10.1017/s000711450000218x

Silla Santos, M.H. (1996). Biogenic amines: their importance in foods. Int. J. Food Microbiol., 29, 213-231. http://dx.doi.org/10.1016/0168-1605(95)00032-1

Stratton, J.E., Hutkins, R.W., \& Taylor, S.L. (1991). Biogenic amines in cheese and other fermented food: A review. J. Food Prot., 54, 460-470.

Straub, B.W., Kicherer, M., Schilcher, S.M., \& Hammes, W.P. (1995). The formation of biogenic amines by fermentation organisms. Zeits. Leb.-Unt. Forsch., 201, 79-82. http://dx.doi.org/10.1007/bf01193205 ten Brink, B., Damink, C., Joosten, H.M., \& Huis in’t Veld, J.H. (1990). Occurrence and formation of biologically active amines in foods. Int. J. Food Microbiol., 11, 73-84. http://dx.doi.org/10.1016/0168-1605(90)90040-c

Teuber, M., Geis, A., \& Neve, H. (1992). The genus Lactococcus. In The Prokaryotes (Vol. II) $2^{\text {nd }}$ edn. (A. Balows, H.G. Truber, M. Dworkin, W. Harder. And K.H. Schleifer, ed.). New York: Springer Verlag.

Wood, B.J.B., \& Holzapfel, W.H. (1995). The genera of lactic acid bacteria. London: Blackie Academic \& Professional. http://dx.doi.org/10.1007/978-14615-5817-0

Zaman, M.Z., Abdula MIR, A.S., Abu Bakar, F., Selamat, J., \& Bakar, J. (2009). A review: microbiological, physicochemical and health impact of high level of biogenic amines in fish sauce. Ame. J. Appl. Sci., 6, 1199-1211. http://dx.doi.org/10.3844/ajassp.2009.1199.1211 